\title{
Delayed diagnosis of a foreign body in the tongue
}

\author{
Nuno Ribeiro Costa, Delfim Duarte, Gustavo Lopes
}

Department of

Otorhinolaryngology, Pedro Hispano Hospital, Porto,

Matosinhos, Portugal

\section{Correspondence to}

Dr Nuno Ribeiro Costa, nunodanielcosta@gmail.com

Accepted 20 October 2016

\section{DESCRIPTION}

A 70 year-old man presented with 1-month history of progressive pain in the tongue after eating fish. The patient stated that he had sought medical care back then, but since no foreign body was found he was discharged with paracetamol. Physical examination revealed a mass located in the middle third of

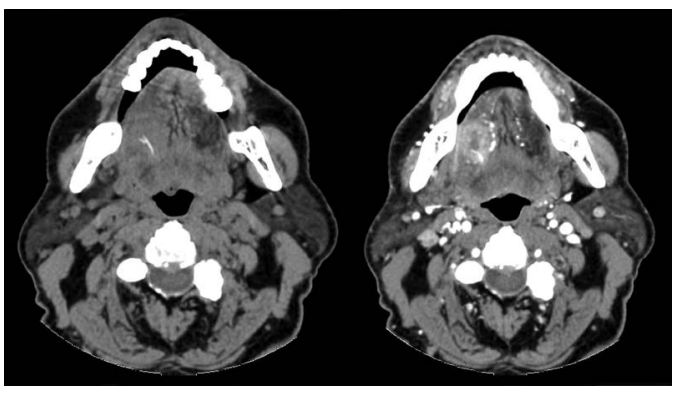

Figure 1 Abscess embedded in the tongue surrounding a radio-opaque foreign body with $\sim 15 \mathrm{~mm}$ in size.

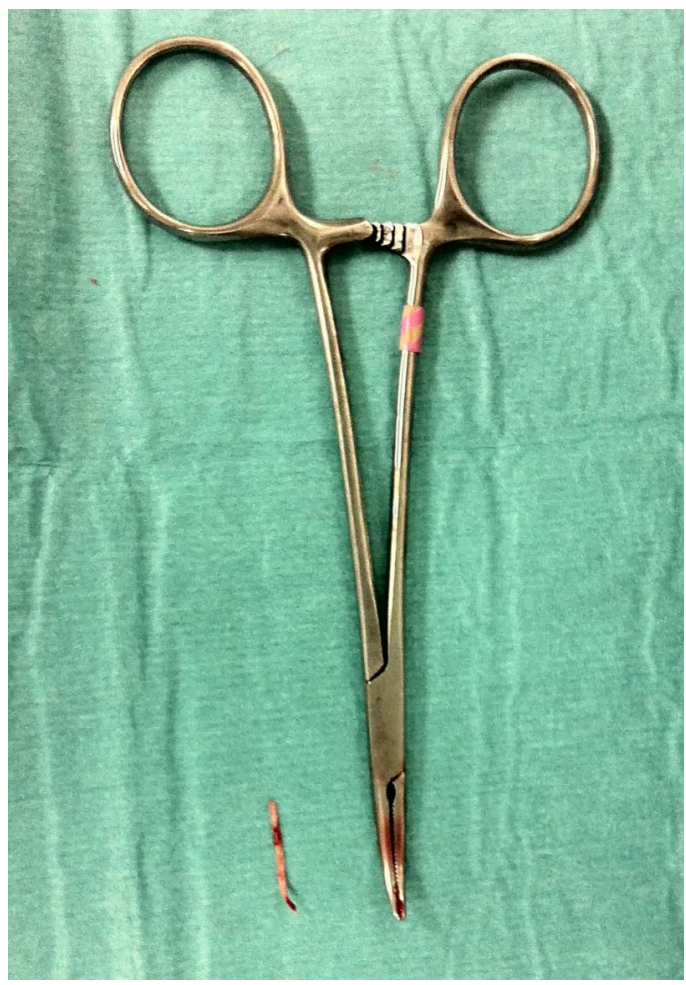

Figure 2 Foreign body removed from the tongue. the right edge of the tongue with $1.5 \mathrm{~cm}$ of diameter, with mild inflammatory signs.

Contrast-enhanced CT scan of the pharynx revealed the presence of an abscess embedded in the tongue surrounding a radio-opaque foreign body (figure 1). A fish bone was removed surgically by making a $1 \mathrm{~cm}$ incision over the mass on the right side of the tongue under general anaesthesia (figure 2). Therapy was complemented with ceftriaxone, clindamycin and methylprednisolone. On 3-month follow-up, the patient had a fully healed tongue with complete regression of the mass and with no neuromuscular sequelae.

Foreign bodies in the upper aerodigestive tract are a frequent emergency in Otorhinolaryngology practice. ${ }^{1}$ Foreign bodies are usually found superficially on the tongue and are easily removed by the patient or the doctor. ${ }^{1}$ However, foreign bodies located deep inside the tongue are a rare occurrence leading frequently to a delayed diagnosis. ${ }^{1} 2$ If left unnoticed a foreign body embedded in the tongue can cause severe infection and consequently airway obstruction and death. ${ }^{13}$

\section{Learning points}

- Deeply embedded foreign body in the tongue musculature are not easily suspected.

- History of trauma should always be questioned.

- Delay in diagnosis can lead to severe and even fatal complications.

Contributors NRC wrote the manuscript. DD and GL were responsible for revising the contents of the manuscript and approving it.

Competing interests None declared.

Patient consent Obtained.

Provenance and peer review Not commissioned; externally pee reviewed.

\section{REFERENCES}

1 Elicora SS, Guven M. Delayed diagnosis of foreign body on the tongue: case report. Braz J Otorhinolaryngol 2012;78:125.

2 Verma R, Sikka K, Thakar A. Autologous embedded foreign body of mobile tongue. Indian J Otolaryngol Head Neck Surg 2007;59:291-2.

3 Buckley SB, Odinet KA, Van Sickels JE. Foreign body in tongue: clinical report. Pediatr Dent 1984;6:102-3. 
Copyright 2016 BMJ Publishing Group. All rights reserved. For permission to reuse any of this content visit http://group.bmj.com/group/rights-licensing/permissions.

BMJ Case Report Fellows may re-use this article for personal use and teaching without any further permission.

Become a Fellow of BMJ Case Reports today and you can:

- Submit as many cases as you like

- Enjoy fast sympathetic peer review and rapid publication of accepted articles

- Access all the published articles

- Re-use any of the published material for personal use and teaching without further permission

For information on Institutional Fellowships contact consortiasales@bmjgroup.com

Visit casereports.bmj.com for more articles like this and to become a Fellow 